\title{
Variation and Profile of Paralytic Shellfish Poisoning Toxins in Jinhae Bay, Korea
}

\author{
Jong-Soo Mok ${ }^{1 *}$, Ki-Cheol Song ${ }^{2}$, Ka-Jeong Lee ${ }^{3}$ and Ji-Hoe Kim ${ }^{3}$ \\ ${ }^{1}$ Southeast Sea Fisheries Research Institute, National Fisheries Research and Development Institute, Tongyoung 650-943, Korea \\ ${ }^{2}$ West Sea Fisheries Research Institute, National Fisheries Research and Development Institute, Incheon 400-420, Korea \\ ${ }^{3}$ Food and Safety Research Division, National Fisheries Research and Development Institute, Busan 619-902, Korea
}

\begin{abstract}
To understand critical aspects of paralytic shellfish poisoning (PSP) in a chief area of bivalve production in Korea, seasonal variation in PSP toxins in bivalves collected from Jinhae Bay, Korea in 2009 was surveyed by the pre-column high-performance liquid chromatography oxidation method. We also confirmed the profiles of major bivalves such as oysters Crassostrea gigas and mussels Mytilus galloprovincialis in Jinhae Bay. PSP toxins in the bivalves showed remarkable seasonal variation. PSP toxin levels were detected from April to May in 2009, and the highest total toxin levels at all stations were recorded in May. The major toxins in bivalves were gonyautoxin [GTX] 1\&4 and C 1\&2; in oysters GTX 2\&3 were also detected as major components. GTX 1\&4, which showed the highest PSP toxin levels at each station, accounted for the highest proportions of toxin components in mussels and oysters (64.5-71.3\% and 41.4-42.4\%, respectively). It was also confirmed that the highest toxicity (in $\mu \mathrm{g}$ saxitoxin [STX] eq/g) was derived from GTX 1\&4. The highest total toxicity (in $\mu \mathrm{g}$ STX eq/g) was approximately 2-8-fold higher in mussels than in oysters collected from the same station. PSP toxin levels in bivalves differed significantly according to the sample collection station. However, the profiles of toxins in the bivalves did not show significant differences during the survey period according to sample collection station. This study shows that PSP toxin levels in some samples from Jinhae Bay were above the regulatory limit in Korea during a specific period in spring.
\end{abstract}

Key words: Paralytic shellfish poisoning, PSP toxin, Bivalve, Jinhae Bay, Crassostrea gigas, Mytilus galloprovincialis

\section{Introduction}

Molluscan shellfish are an important food resource, but contamination with natural toxins is a worldwide problem. Shellfish toxins are natural toxins that have been detected in molluscan shellfish, such as mussels, oysters, scallops, and clams. Contaminated shellfish pose a risk to human health if consumed. Shellfish toxins that contaminate bivalves include saxitoxin (STX) and its derivatives, which cause paralytic shellfish poisoning (PSP); okadaic acid (OA) group toxins, which cause diarrhetic shellfish poisoning (DSP); domoic acid (DA), which causes amnesic shellfish poisoning (ASP); and azaspiracid (AZA) group toxins, which cause azaspiracid shellfish poisoning (AZP) (Noguchi, 2003; Toyofuku, 2006). The toxins are produced mainly by algae or phytoplankton, and can accumulate in the digestive gland (hepatopancreas) of filter-feeding molluscan shellfish. They cause diseases with both gastrointestinal and neurologic symptoms in humans (Edebo et al., 1988; Silvert and Subba Rao, 1992; Indrasena and Gill, 2000; Toyofuku, 2006).

PSP toxins are produced mainly by dinoflagellates belonging to the Alexandrium, Gymnodinium, and Pyrodinium
Open Access http://dx.doi.org/10.5657/FAS.2013.0137

This is an Open Access article distributed under the terms of the Creative Commons Attribution Non-Commercial License (http://creativecommons. org/licenses/by-nc/3.0/) which permits unrestricted non-commercial use, distribution, and reproduction in any medium, provided the original work is properly cited. pISSN: 2234-1749 eISSN: 2234-1757
Received 22 May 2013; Revised 15 July 2013

Accepted 16 July 2013

*Corresponding Author

E-mail: mjs0620@korea.kr 
genera. The amounts of PSP toxins in shellfish are closely correlated with the density of toxin-related phytoplankton (Toyofuku, 2006). The toxins accumulate in shellfish, and consumption of toxic shellfish can lead to serious illness, and death in extreme cases (Noguchi, 2003). Many cases of PSP have been reported in various countries (Chang et al., 1989; Determan, 2003; Noguchi, 2003; Toyofuku, 2006), including Korea (Chang et al., 1987; Lee et al., 1997). Moreover, PSP-causing toxins are detected annually in Jinhae Bay, Korea (Chang et al., 1989; Park et al., 2000; Shon et al., 2009). To protect public health, the authorities of many countries, such as Korea, the USA, Japan, Canada, and those comprising the EU, have established monitoring programs for PSP toxins to determine whether it is safe to harvest and consume shellfish. The regulatory limit is $80 \mu \mathrm{g}$ per 100-g shellfish tissue (Chang et al., 1987; Determan, 2003; Noguchi, 2003; Wekell et al., 2004; Toyofuku, 2006; Rourke et al., 2008).

In our previous study, the accumulation and occurrence of PSP toxins in various bivalves in Jinhae Bay was assessed by mouse bioassay (MBA) (Mok et al., 2012), and a comparison study of MBA and pre-column high-performance liquid chromatography (HPLC) oxidation methods was conducted in mussels (Mok et al., 2013). Since aquaculture is the main source of mussels and oysters in Korea, the monitoring of PSP toxins in shellfish farming areas is important for both the industry and the consumer. In the present study, seasonal variation in PSP toxins in bivalves collected from Jinhae Bay in Korea was surveyed by pre-column HPLC oxidation. We also confirmed the profiles in the major bivalves, such as oysters Crassostrea gigas and mussels Mytilus galloprovincialis, in Jinhae Bay.

\section{Materials and Methods}

\section{Reagents}

All solvents and reagents for sample preparation and HPLC analysis were of analytical or HPLC grade. Hydrochloric acid, sodium phosphate, hydrogen peroxide, acetic acid, methanol, acetonitrile, and acetic acid were obtained from Merck (Darmstadt, Germany). Sodium hydroxide and periodic acid were purchased from Sigma (St. Louis, MO, USA). Ammonium formate was obtained from Fluka (Buchs, Germany). The oxidant solution for periodate oxidation was prepared by mixing $5 \mathrm{~mL}$ each of $0.03 \mathrm{M}$ periodic acid, $0.3 \mathrm{M}$ ammonium formate, and $0.3 \mathrm{M}$ sodium phosphate $\left(\mathrm{Na}_{2} \mathrm{HPO}_{4}\right)$, and adjusting the $\mathrm{pH}$ to 8.2 with $0.2 \mathrm{M}$ sodium hydroxide. De-ionized water was passed through a Milli-Q water purification system (Millipore, Bedford, MA, USA) and used for the preparation of HPLC mobile phases.

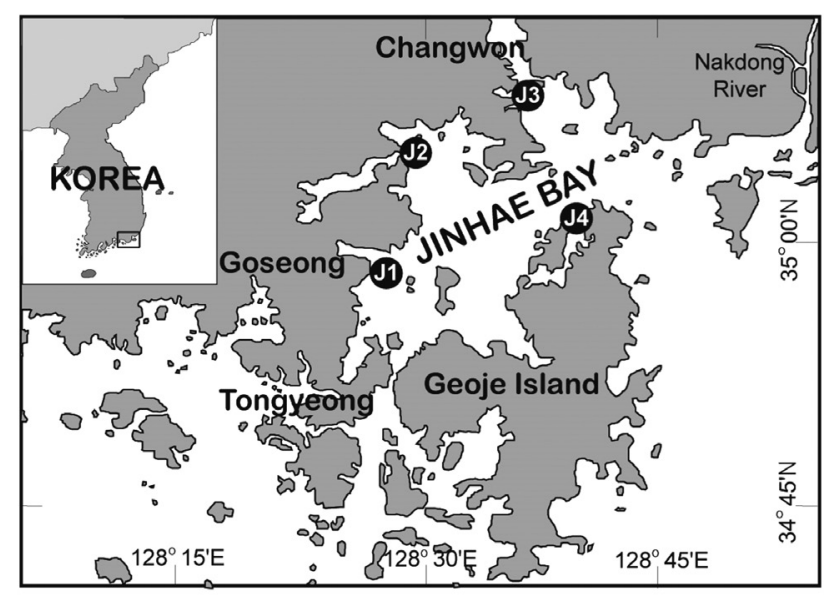

Fig. 1. Sampling locations in the Jinhae Bay, Korea.

\section{Standard toxins}

Certified reference materials (STX, decarbamonyl STX [dc STX], neoSTX [NEO], gonyautoxin [GTX] 1\&4, GTX 2\&3, decarbamonyl GTX [dcGTX] 2\&3, GTX 5, and N-sulfocarbamoylgonyautoxin C [C] 1\&2) were purchased from the Institute for Marine Biosciences of the National Research Council (Halifax, Nova Scotia, Canada) in glass ampoules as solutions in $0.1 \mathrm{M}$ acetic acid. Stock standard solutions were prepared by diluting primary toxin standard solutions in water eight times. Working standard solutions were prepared by dilution of stock solutions in $0.1 \mathrm{mM}$ acetic acid to produce instrument calibration standards for use in analysis of PSP toxins by precolumn HPLC oxidation.

\section{Field sampling}

Samples for analysis of PSP toxins were collected at fixed monitoring stations in Jinhae Bay in Korea in 2009 (Fig. 1). Bivalve samples such as cultured mussel $M$. galloprovincialis and oyster $C$. gigas were collected at 2- to 3-m depths from a hanging rope culture. In Jinhae Bay, 88 mussel samples were collected from stations $\mathrm{J} 1, \mathrm{~J} 2, \mathrm{~J} 3$, and J4, while 95 oyster samples were collected from stations J1, J2, and J4 (Fig. 1). Bivalve samples were received in conditions suitable for analysis, preferably chilled in cooling boxes. To minimize the variation between individual bivalves, one sample unit was composed of more than 12 animals from the same station. Water temperature was measured at the depths at which the shellfish were collected using a YSI 556 Multi-Probe System (Yellow Springs, OH, USA).

\section{Sample extraction}

The outside of each shellfish was thoroughly cleaned with 

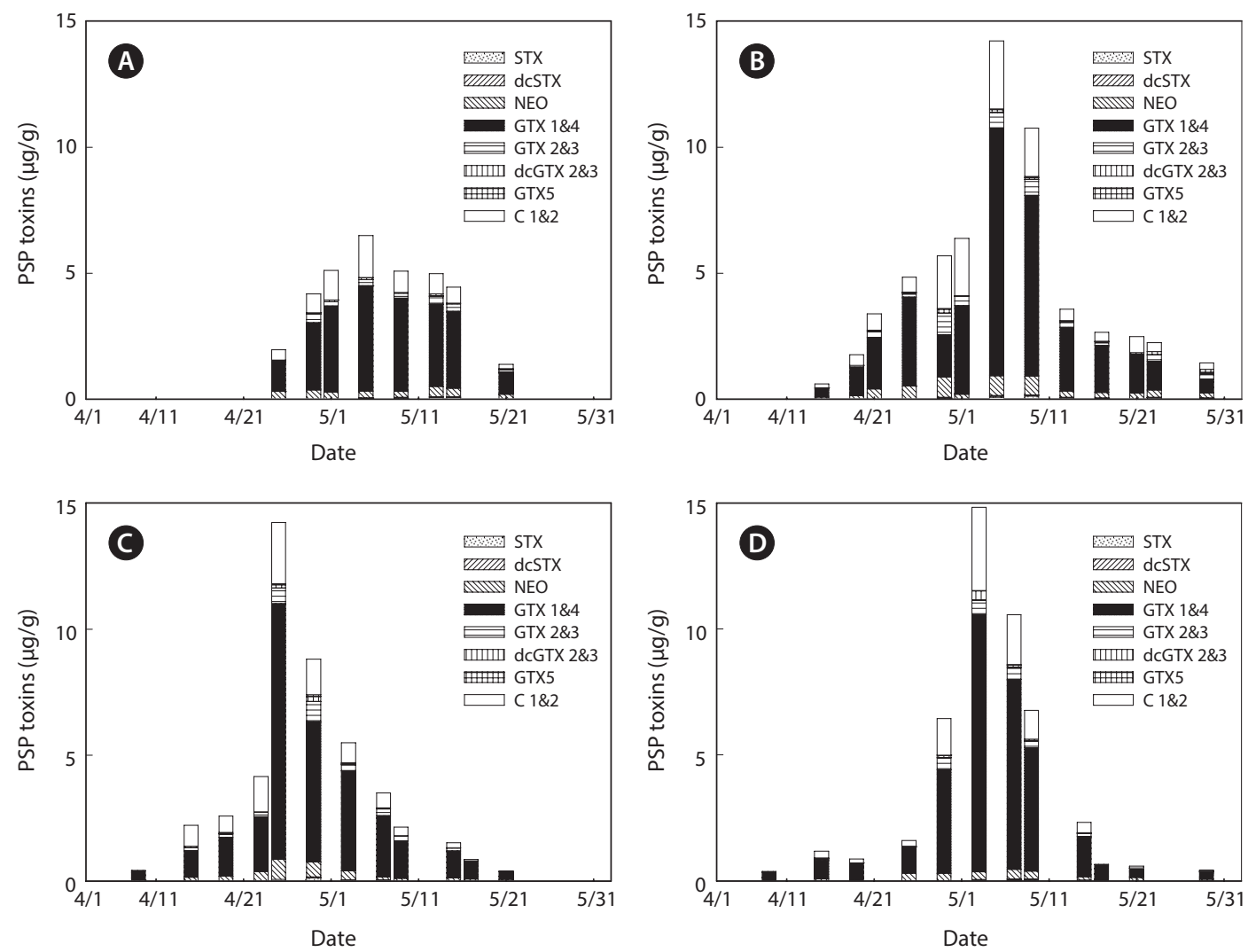

Fig. 2. Variation of paralytic shellfish poisoning (PSP) toxins in mussels Mytilus galloprovincialis at station J1 (A), at station J2 (B), at station J3 (C), and at station J4 (D) in the Jinhae Bay, Korea, in 2009. STX, saxitoxi; dcSTX, decarbamonyl STX; NEO, neoSTX; GTX, gonyautoxin; dcGTX, decarbamonyl GTX; C, $\mathrm{N}$-sulfocarbamoylgonyautoxin C.

fresh water. The shellfish samples were shucked, and drained onto a No. 10 sieve for $5 \mathrm{~min}$. A 10-g portion of homogenized shellfish tissue was extracted by boiling for $5 \mathrm{~min}$ in $10 \mathrm{~mL}$ of $0.1 \mathrm{M} \mathrm{HCl}$ according to the extraction method of Lawrence and Niedzwiadek (2001). The crude extracts were centrifuged at 5,000 $\mathrm{g}$ for $10 \mathrm{~min}$, and the supernatant was made up to a volume of $20 \mathrm{~mL}$ with water.

\section{SPE $\mathrm{C}_{18}$ clean up and oxidation}

A 1-mL sample of the crude extract was passed through a SPE $\mathrm{C}_{18}$ cartridge ( $3 \mathrm{~mL}$; Supelco, Bellefonte, PA, USA) previously conditioned with $6 \mathrm{~mL}$ of methanol followed by 6 $\mathrm{mL}$ of water. The effluent was collected, and the cartridge was washed with $2 \mathrm{~mL}$ of water, which was combined with the effluent. For the oxidation reactions, the volume was made up to $4 \mathrm{~mL}$ with water. For HPLC analysis, the sample extracts were oxidized using both periodate and peroxide, as described by Lawrence and Niedzwiadek (2001).

\section{HPLC analysis}

Analysis of the PSP toxins was carried out by the pre-col- umn HPLC oxidation method. The HPLC unit consisted of a Surveyor MS Pump Plus pump and a Surveyor AS Plus needle assembly (Thermo Electron, San Jose, CA, USA). A fluorescence detector (Finnigan Surveyor FL Plus Detector; Thermo Electron) was used for detection of toxins. Fluorescence excitation was set to $340 \mathrm{~nm}$ and emission to $395 \mathrm{~nm}$. The column used was a Supelcosil C-18 column $(15 \mathrm{~cm} \times 4.6 \mathrm{~mm}$ id, $5 \mu \mathrm{m}$; Supelco). Mobile phase A was $0.1 \mathrm{M}$ ammonium formate and mobile phase B was $0.1 \mathrm{M}$ ammonium formate with 5\% acetonitrile. The analytical conditions were as described previously (Mok et al., 2013).

\section{Results and Discussion}

The variability of PSP toxin levels in the bivalves at each sampling station in Jinhae Bay in 2009 is shown in Figs. 2 and 3. PSP toxin levels in the bivalves, except in April and May 2009, are not shown in the figures, because no toxins were detected. During the survey period, PSP toxins in mussels were detected in 45 of 88 samples collected at four stations (Fig. 2), while toxins in oysters were detected in 15 of 95 samples collected at three stations (Fig. 3). The PSP toxin 

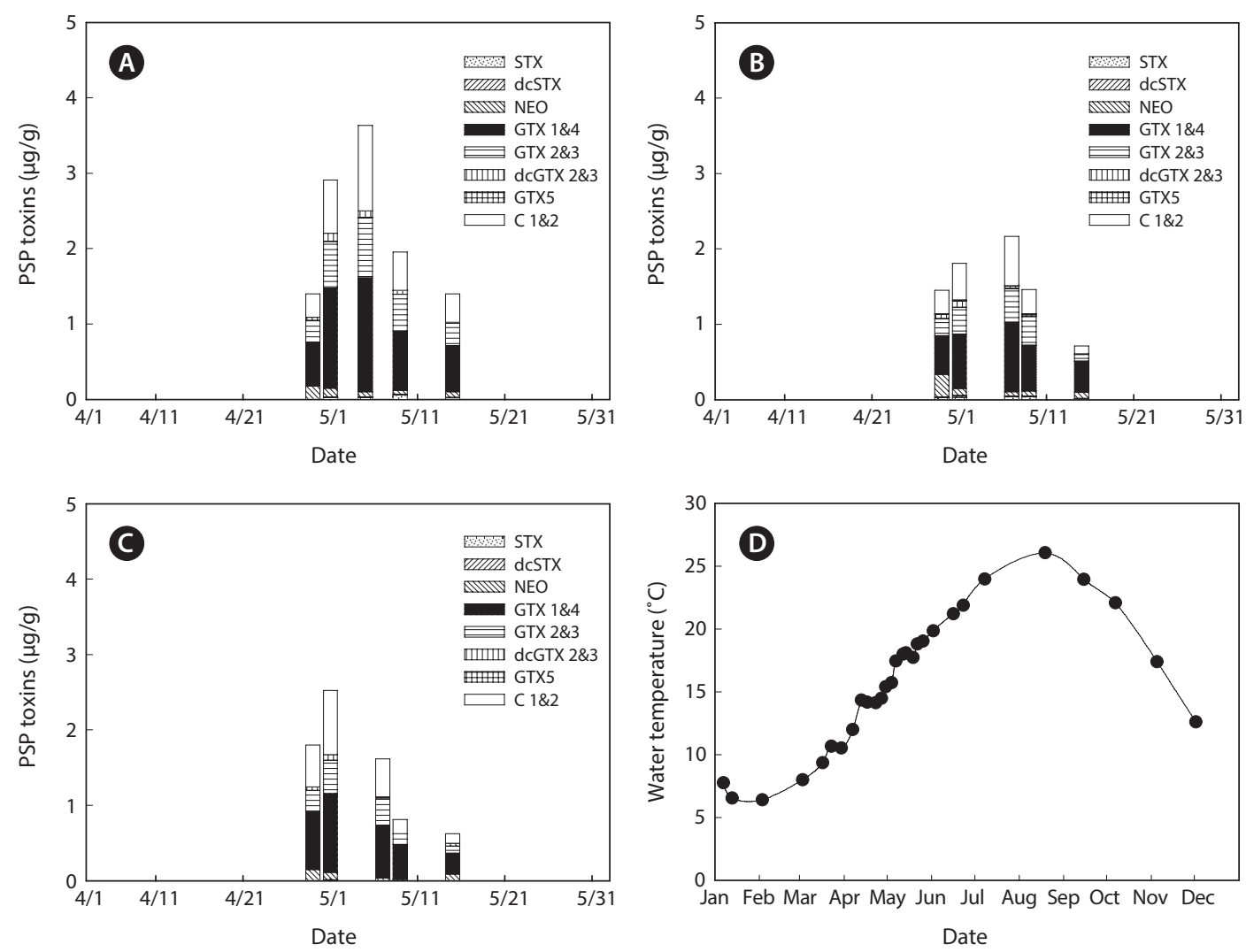

Fig. 3. Variation of paralytic shellfish poisoning (PSP) toxins in oysters Crassostrea gigas at station J1 (A), at station J2 (B), at station J4 (C), and water temperature (D) in the Jinhae Bay, Korea, in 2009. STX, saxitoxin; dcSTX, decarbamonyl STX; NEO, neoSTX; GTX, gonyautoxin; dcGTX, decarbamonyl GTX; C, $\mathrm{N}$-sulfocarbamoylgonyautoxin C.

levels in the bivalves showed remarkable seasonal variation. The overall seasonal trend showed that high toxicities were a problem during spring. The highest total toxin levels in 2009 at all stations were recorded in May (Figs. 2 and 3). We previously reported that high amounts of PSP toxins were detected in bivalves in Jinhae Bay in spring 2005 and 2006 by MBA (Mok et al., 2012). Many authors have reported high levels of PSP toxins during spring in Jinhae Bay (Chang et al., 1989; Park et al., 2000; Shon et al., 2009).

Variation in mean surface water temperature in Jinhae Bay in 2009 is shown in Fig. 3D. During the survey period, the water temperature ranged from $6.4^{\circ} \mathrm{C}$ in February to $26.1^{\circ} \mathrm{C}$ in August. For the period in which PSP toxins were detected in bivalves, the water temperature ranged from $12.0^{\circ} \mathrm{C}$ in April to $19.0^{\circ} \mathrm{C}$ in May. The variation in PSP toxin levels was closely related to water temperature, because the toxins are produced mainly by dinoflagellates (Noguchi, 2003; Toyofuku, 2006).

A specific difference in the profiles and levels of PSP toxins was observed between mussels and oysters collected at the same station during the survey period. The profiles of PSP toxins in bivalves containing the highest PSP toxin levels at each station during the survey period are shown in Table 1. The major toxins in bivalves were GTX $1 \& 4$ and C $1 \& 2$, but
GTX 2\&3 was also detected as a major component in oysters. Some toxins, such as STX, dcSTX, dcGTX 2\&3, and GTX 5, were detected at levels of below $5 \%$ in bivalves. In mussels, GTX 1\&4 accounted for the highest proportion (64.5-71.3\%) of toxin components, followed (in order) by C $1 \& 2(17.1$ 25.7\%), NEO (2.1-5.6\%), GTX $2 \& 3$ (3.7-4.4\%), dcGTX $2 \& 3$ $(0.8-2.4 \%)$, STX (1.0-0.6\%), deSTX $(<0.1-0.3)$, and GTX 5 (0.1-0.3\%). In oysters, GTX $1 \& 4$ showed the highest proportion (41.4-42.4\%), followed (in order) by C $1 \& 2$ (30.0$33.7 \%)$, GTX $2 \& 3(17.4-22.1 \%)$, NEO (1.9-3.9\%), dcGTX $2 \& 3(1.8-3.0 \%), \operatorname{STX}(0.5-1.9 \%)$, deSTX $(<0.1-0.3)$, and GTX 5 (ND-0.1\%). It was also confirmed that the greatest toxicity (in $\mu \mathrm{g}$ STX eq/g) was derived from GTX $1 \& 4$ (Table 2). Park et al. (2000) also profiled PSP toxins in various bivalves from Jinhae Bay in 1997. They reported that GTX 1\&4 accounted for $48.4 \%$ of toxin components in mussels, and identified them as a dominant ingredient. Shon et al. (2009) reported that the most abundant toxin components identified in mussels from Jinhae Bay were GTX 1 and GTX 4, followed by C 1, C 2, GTX 3, and neoSTX. A similar trend was observed in this study.

The contents of PSP toxins in the bivalves containing the highest PSP toxin levels at each station during the survey pe- 
riod are shown in Table 2. At station $\mathrm{J} 4$, a total toxicity of 7.18 $\mu \mathrm{g}$ STX eq/g was detected in mussels on April 30; in comparison, a total toxicity of $0.97 \mu \mathrm{g}$ STX eq/g was measured in oysters collected on the same day. At stations J1, J2, J4, the highest total toxicity in mussels was approximately 4-9-fold the regulatory limit of $80 \mu \mathrm{g}$ STX eq/100 g, whereas that in oysters from the same station was 1.1-1.8-fold the regulatory limit. Therefore, mussels accumulated more PSP toxins than did oysters. We previously compared the accumulation of PSP toxins in bivalve species from Jinhae Bay in 2005 and 2006. Our data showed that the maximum toxin levels in mussels were 1.6-2.0-, 4.0-5.9-, and 5.1-6.0-fold higher than those in bay scallops, oysters, and short-neck clams, respectively (Mok et al., 2012). Park et al. (2000) also conducted an analysis of PSP toxins in various bivalves from Jinhae Bay in 1997. They found that the toxin levels in mussels were 2.5-, 6.0-, and 7.0-fold higher than those in short-neck clams, oysters, and ark shells, respectively. The same trend was observed in this study. Therefore, mussels could be useful as a bioindica- tor for PSP toxin monitoring in Korea. Mizuta et al. (1999) analyzed the PSP toxins in mussels and oysters collected from the same area periodically, and found that toxin levels were threefold higher in mussels than in oysters.

The levels of PSP toxins in the bivalves differed significantly according to sample collection station. The highest total toxin level in mussels was measured at station J4 (Table 2, Fig. 2), while that in oysters was found at station J1 (Table 2, Fig. $3)$. However, the profiles of toxins in the bivalves during the survey period did not differ significantly according to sample collection station.

Korea is the fourth largest producer of shellfish, accounting for almost $2.8 \%$ of the global harvest (Lee et al., 2011). Korean shellfish products are exported to mainly the USA, China, Japan, and the EU (Pawiro, 2010; Rees et al., 2010). Jinhae Bay is an important shellfish growing area in Korea, because it produces various shellfish, such as mussels, oysters, ark shells, short-neck clams, butter clams, soft-shell clams, and comb pen shells. This bay is a typical semi-enclosed coastal

Table 1. Profiles of PSP toxins $(\mu \mathrm{g} / \mathrm{g})$ in the bivalves collected from Jinhae Bay of Korea in 2009

\begin{tabular}{lcccccccccc}
\hline \multirow{2}{*}{ Bivalves $^{*}$} & Stations & \multicolumn{8}{c}{ Composition of PSP toxins (\%) $^{\dagger}$} \\
\cline { 3 - 10 } & & STX & deSTX & NEO & GTX 1\&4 & GTX 2\&3 & dcGTX 2\&3 & GTX 5 & C 1\&2 & Sum \\
\hline \multirow{2}{*}{ Mussel } & J1 & 0.3 & 0.3 & 4.2 & 64.5 & 3.7 & 1.2 & 0.1 & 25.7 & 100 \\
& J2 & 0.6 & 0.3 & 5.6 & 69.1 & 4.4 & 0.8 & 0.2 & 19.0 & 100 \\
& J3 & 0.5 & $<0.1$ & 5.6 & 71.3 & 4.3 & 0.9 & 0.3 & 17.1 & 100 \\
& J4 & 0.1 & 0.2 & 2.1 & 68.8 & 4.0 & 2.4 & 0.1 & 22.3 & 100 \\
Oyster & J1 & 0.9 & $<0.1$ & 1.9 & 41.6 & 22.1 & 2.4 & ND & 31.1 & 100 \\
& J2 & 1.9 & 0.3 & 2.8 & 42.4 & 20.7 & 1.8 & 0.1 & 30.0 & 100 \\
& J4 & 0.5 & 0.1 & 3.9 & 41.4 & 17.4 & 3.0 & ND & 33.7 & 100 \\
\hline
\end{tabular}

PSP, paralytic shellfish poisoning; STX, saxitoxin; dcSTX, decarbamonyl STX; NEO, neoSTX; GTX, gonyautoxin; dcGTX, decarbamonyl GTX; C, N-sulfocarbamoylgonyautoxin $\mathrm{C} ; \mathrm{ND}$, not detectable.

"The bivalve samples contained the highest PSP toxin levels at each station during the survey period as shown in Figs. 1 and $2,^{\dagger}$ The compositions of PSP toxins were calculated as each toxin content $(\mu \mathrm{g} / \mathrm{g})$ per total toxin content $(\mu \mathrm{g} / \mathrm{g}) \times 100$.

Table 2. Profiles of relative toxicity ( $\mu \mathrm{g} \mathrm{STX} \mathrm{eq/g)*} \mathrm{of} \mathrm{PSP} \mathrm{toxins} \mathrm{in} \mathrm{the} \mathrm{bivalves} \mathrm{collected} \mathrm{from} \mathrm{Jinhae} \mathrm{Bay} \mathrm{of} \mathrm{Korea} \mathrm{in} 2009$

\begin{tabular}{|c|c|c|c|c|c|c|c|c|c|c|c|}
\hline \multirow{2}{*}{ Bivalve $^{\dagger}$} & \multirow{2}{*}{ Station } & \multicolumn{9}{|c|}{ Composition of relative toxicity $(\%)^{\ddagger}$} & \multirow{2}{*}{$\begin{array}{l}\text { Total toxicity } \\
\text { ( } \mu \text { g STX eq/g) }\end{array}$} \\
\hline & & STX & deSTX & NEO & GTX $1 \& 4$ & GTX 2\&3 & dcGTX $2 \& 3$ & GTX 5 & $\mathrm{C} 1 \& 2$ & Sum & \\
\hline \multirow[t]{4}{*}{ Mussel } & $\mathrm{J} 1$ & 0.7 & 0.5 & 7.7 & 85.7 & 3.0 & 0.7 & $<0.1$ & 1.7 & 100 & 3.08 \\
\hline & $\mathrm{J} 2$ & 1.2 & 0.4 & 9.4 & 84.1 & 3.2 & 0.5 & $<0.1$ & 1.2 & 100 & 7.36 \\
\hline & $\mathrm{J} 3$ & 0.9 & $<0.1$ & 9.3 & 85.1 & 3.1 & 0.5 & $<0.1$ & 1.1 & 100 & 7.52 \\
\hline & $\mathrm{J} 4$ & 0.3 & 0.2 & 3.9 & 89.5 & 3.1 & 1.5 & $<0.1$ & 1.5 & 100 & 7.18 \\
\hline \multirow[t]{3}{*}{ Oyster } & $\mathrm{J} 1$ & 2.2 & 0.1 & 4.2 & 67.5 & 21.6 & 1.8 & ND & 2.6 & 100 & 1.41 \\
\hline & $\mathrm{J} 2$ & 4.7 & 0.4 & 6.0 & 65.8 & 19.4 & 1.3 & $<0.1$ & 2.4 & 100 & 0.88 \\
\hline & $\mathrm{J} 4$ & 1.3 & 0.1 & 8.8 & 67.5 & 17.1 & 2.4 & ND & 2.8 & 100 & 0.97 \\
\hline
\end{tabular}

PSP, paralytic shellfish poisoning; STX, saxitoxin; dcSTX, decarbamonyl STX; NEO, neoSTX; GTX, gonyautoxin; dcGTX, decarbamonyl GTX; C, N-sulfocarbamoylgonyautoxin $C ; N D$, not detectable.

"Relative toxicity ( $\mu \mathrm{g}$ STX eq/g) of PSP toxins were obtained from Lawrence et al. (2005), ${ }^{\dagger}$ The bivalve samples contained the highest PSP toxin levels at each station during the survey period as shown in Figs. 1 and $2,{ }^{\ddagger}$ The compositions of relative toxicity of PSP toxins were calculated as each relative toxicity ( $\mu$ g $\mathrm{STX}$ eq/g) per total relative toxicity $(\mu \mathrm{g}$ STX eq/g) $\times 100$. 
area surrounded by populated cities and is one of the most eutrophic coastal bays in Korea. The bay is known for recurring red-tide blooms, including Alexandrium tamarense bloom (Lee et al., 2003). PSP toxins are detected annually in bivalves in Jinhae Bay during the spring season (Chang et al., 1989; Park et al., 2000; Shon et al., 2009; Mok et al., 2012). DSP toxins were also detected at levels below the Korean regulatory limit in bivalves from Jinhae Bay from 2007 to 2009 (Lee et al., 2011). Thus, the occurrence of shellfish toxins in Korea is considered important for both Korea and importing countries.

Contamination of shellfish by PSP toxins and cases of PSP have been reported in various countries (Chang et al., 1989; Determan, 2003; Noguchi, 2003; Toyofuku, 2006). Thus, PSP is a serious global public health problem. Our data suggest that the PSP toxin levels in some samples from Jinhae Bay were above the regulatory limit during a specific period in spring. The health of consumers who eat bivalves containing such levels of PSP toxins could be at risk. Therefore, the Korean government operates a monitoring program and an early warning system to ensure the safety of shellfish for consumption.

\section{Acknowledgements}

This work was supported by a grant from National Fisheries Research and Development Institute of Korea (RP-2013FS-035).

\section{References}

Chang DS, Shin IS, Pyeun JH and Park YH. 1987. A Study on paralytic shellfish poison of sea mussel, Mytilus edulis. Food poisoning accident in Gamchun Bay, Pusan, Korea, 1986. Bull Korean Fish Soc 20, 293-299.

Chang DS, Shin IS, Kim JH, Pyun JH and Choe WK. 1989. Detoxification of PSP and relationship between PSP toxicity and Protogonyaulax sp. Bull Korean Fish Soc 22, 177-188.

Determan M. 2003. Paralytic Shellfish Poisoning (PSP) Patterns in Puget Sound Shellfish in 2001. Washington State Department of Health, Olympia, WA, US, pp. 1-12.

Edebo L, Lange S, Li XP, Allenmark S, Lindgren K and Thompson R. 1988. Seasonal, geographic, and individual variation of okadaic acid content in cultivated mussels in Sweden. APMIS 96, 10361042.

Indrasena WM and Gill TA. 2000. Thermal degradation of partially purified paralytic shellfish poison toxins at different times, temperatures and $\mathrm{pH}$. J Food Sci 65, 948-953. http://dx.doi. org/10.1111/j.1365-2621.2000.tb09398.x.

Lawrence JF and Niedzwiadek B. 2001. Quantitative determination of paralytic shellfish poisoning toxins in shellfish using prechromatographic oxidation and liquid chromatography with fluorescence detection. J AOAC Int 84, 1099-1108.
Lee HO, Choi KH and Han MS. 2003. Spring bloom of Alexandrium tamarense in Chinhae Bay, Korea. Aquat Microb Ecol 33, 271278. http://dx.doi.org/10.3354/ame033271.

Lee JS, Shin IS, Kim YM and Chang DS. 1997. Paralytic shellfish toxins in the mussel, Mytilus edulis, caused the shellfish poisoning accident at Geoje, Korea, in 1996. J Korean Fish Soc 30, 158-160.

Lee KJ, Mok JS, Song KC, Yu HS, Jung JH and Kim JH. 2011. Geographical and annual variation in lipophilic shellfish toxins from oysters and mussels along the south coast of Korea. J Food Prot 74, 2127-2133. http://dx.doi.org/10.4315/0362-028X.JFP-11-148.

Mizuta M, Yamada K, Takata K, Shimaoka M, Takayama H and Ouchi A. 1999. Differences of accumulation and elimination of paralytic shellfish poisons among oyster, mussel and scallop. J Food Hyg Soc Jpn 40, 19-22. http://dx.doi.org/10.3358/shokueishi.40.19.

Mok JS, Oh EG, Son KT, Lee TS, Lee KJ, Song KC and Kim JH. 2012. Accumulation and depuration of paralytic shellfish poison in marine organisms. Korean J Fish Aquat Sci 45, 465-471. http://dx.doi. org/10.5657/KFAS.2012.0465.

Mok JS, Song KC, Lee KJ and Kim JH. 2013. Validation of precolumn HPLC oxidation method for analysis of paralytic shellfish poison. Korean J Fish Aquat Sci 46, 147-153. http://dx.doi.org/10.5657/ KFAS.2013.0147.

Noguchi T. 2003. Marine toxins. Nippon Suisan Gakkaishi 69, 895-909. http://dx.doi.org/10.2331/suisan.69.895.

Park MJ, Lee HJ, Lee TS, Son KT, Byun HS, Park JH and Jang DS. 2000. Comparison of paralytic shellfish poison contents and components in the different bivalve species. J Food Hyg Saf 15, 293296.

Pawiro S. 2010. Bivalves: global production and trade trends. In: Safe Management of Shellfish and Harvest Waters. Rees G, Pond K, Kay D, Bartram J and Domingo JS, eds. World Health Organization, IWA Publishing, London, GB, pp. 11-19.

Rees G, Bartram J and Kay D. 2010. Expert consensus. In: Safe Management of Shellfish and Harvest Waters. Rees G, Pond K, Kay D, Bartram J and Domingo JS, eds. World Health Organization, IWA Publishing, London, GB, pp. 1-10.

Rourke WA, Murphy CJ, Pitcher G, van de Riet JM, Burns BG, Thomas KM and Quilliam MA. 2008. Rapid postcolumn methodology for determination of paralytic shellfish toxins in shellfish tissue. $\mathrm{J}$ AOAC Int 91, 589-597.

Shon MB, Kim YS and Kim CR. 2009. Paralytic shellfish poisoning of Mediterranean mussels from Jinhae Bay in Korea. Korean J Fish Aquat Sci 42, 366-372. http://dx.doi.org/10.5657/ KFAS.2009.42.4.366.

Silvert W and Subba Rao DV. 1992. Dynamic model of the flux of domoic acid, a neurotoxin, through a Mytilus edulis population. Can J Fish Aquat Sci 49, 400-405. http://dx.doi.org/10.1139/f92045 .

Toyofuku H. 2006. Joint FAO/WHO/IOC activities to provide scientific advice on marine biotoxins (research report). Mar Pollut Bull 52, 1735-1745. http://dx.doi.org/10.1016/j.marpolbul.2006.07.007.

Wekell JC, Hurst J and Lefebvre KA. 2004. The origin of regulatory limits for PSP and ASP toxins in shellfish. J Shellfish Res 23, 927930 . 